\title{
Effect of Microgravity on Most Frequently Isolated Microorganisms from Cosmetics
}

\author{
Daniel Juwon Arotupin ${ }^{1}$, Tosin Victor Adegoke ${ }^{1, ~ *}$, Kehinde Olusayo Awojobi \\ Temitope Samuel Aderanti ${ }^{1}$
}

${ }^{1}$ Department of Microbiology, The Federal University of Technology, Akure, Nigeria

${ }^{2}$ Department of Microbiology, Obafemi Awolowo University, Ile-Ife, Nigeria

Email address:

tosinadegoke64@yahoo.com (T. V. Adegoke)

${ }^{*}$ Corresponding author

\section{To cite this article:}

Daniel Juwon Arotupin, Tosin Victor Adegoke, Kehinde Olusayo Awojobi, Temitope Samuel Aderanti. Effect of Microgravity on Most Frequently Isolated Microorganisms from Cosmetics. International Journal of Biomedical Materials Research. Vol. 7, No. 2, 2019, pp. 67-71. doi: 10.11648/j.ijbmr.20190702.11

Received: February 13, 2019; Accepted: June 27, 2019; Published: August 14, 2019

\begin{abstract}
Microorganisms associated with commonly used cosmetics and effects of microgravity on most frequently isolated microorganism were investigated. The microorganisms isolated from the cosmetics were Staphylococcus aureus, Pseudomonas aeruginosa, Escherichia coli, Proteus mirabilis, Bacillus cereus, Proteus vulgaris, Bacillus subtilis, Trichoderma piluliferum and Neocosmospora vasinfecta. Fifty percent of the cosmetics were contaminated with Staphylococcus aureus, 31.82\% contaminated with Pseudomonas aeruginosa, $22.73 \%$ contaminated with Escherichia coli, 13.64\% contaminated with Proteus mirabilis, 13.64\% contaminated with Bacillus cereus, 9.09\% contaminated with Proteus vulgaris, $4.55 \%$ contaminated with Bacillus subtilis, $13.64 \%$ contaminated with Trichoderma piluliferum and $9.09 \%$ contaminated with Neocosmospora vasinfecta. The $S$. aureus which was the most frequently isolated bacteria was subjected to microgravity condition. The antibiotics susceptibility test of the most frequent bacteria (S. aureus) was investigated and it was observed that the $S$. aureus grown under stimulated microgravity condition exhibited resistance to antibiotic more than $S$. aureus grown under earth gravity. The most frequently isolated bacteria namely $S$. aureus exhibited greater resistance to antibiotics under stimulated microgravity condition than one under earth gravity condition at different time. The resistance of the $S$. aureus to antibiotics tends to increase with increased in revolution per minutes (rpm) at which the bacterium was subjected.
\end{abstract}

Keywords: Cosmetics, Microorganisms, Contamination, Antibiotics, Microgravity, Rmp

\section{Introduction}

Preservatives are used in all sorts of products in which microorganisms can proliferate. Food, pharmaceuticals, industrial products, household products and cosmetics are some of the products that are at risk of contamination by microorganisms. Presently, the cosmetic industry uses numerous ingredients, including preservatives, moisturizers, thickeners, antimicrobials, solvents, emulsifiers and colours in the production processes. Pathogenic microorganisms such as Staphylococcus aureus and Pseudomonas aeruginosa are frequently encountered in contaminated cosmetics [1].

Microbes are highly evolved and occupy unique environmental niches. In order for the plethora of microbes to persist and thrive, they must be highly responsive to change in their local environments in which they are constantly exposed. Some of these environmental changes are experienced in the form of temperature, oxidative, host cell induced, and/or chemical stresses [2]. Microbial existence and survival requires the ability to sense and respond to environmental changes, including changes in physical forces as well as mutant availability and accessibility. This is because microbes inhabit an amazingly diverse range of ecological niches and therefore, must constantly adapt to a wide variety of changing environmental conditions, including alterations in temperature, $\mathrm{pH}$, nutrient availability, oxygen levels, and osmotic pressure gradients [3-8]. 
Recently, several important studies have demonstrated a key role for microgravity and the low fluid shear dynamics associated with microgravity in the regulation of microbial gene expression, physiology, and pathogenesis [9-13]. Diminished gravity or 'microgravity' as it is termed, weakens humans and makes bacteria stronger, more difficult to kill, and more accomplished at causing disease [14].

Bone decalcification and loss are well documented in astronauts during space travel and residence. This predisposes them to bone fracture as well as kidney stones from resorbed bone material [14]. In microgravity, muscles atrophy and blood production decreases. The latter results in diminished pumping by the heart and, combined with the concomitant blood shift to the upper torso, can damage heart muscles [14]. Effect of microgravity on bacteria decreased antibiotics effectiveness against such bacteria.

The objective of this study was to examine the assessment of microorganisms associated with commonly used cosmetics and the effect of microgravity on the most frequently isolated microbe.

\section{Material and Methods}

\subsection{Sources of the Test Bacteria}

The test microorganism used in the course of the research was the most frequent isolated microorganism ( $S$. aureus) from cosmetic.

\subsection{Standardization of Test Bacteria}

A loopful of the bacterial culture was aseptically inoculated into freshly prepared sterile nutrient broth and incubated for 24 hours. Zero-point-Two was pipetted from the 24 hours broth culture of the test organism, dispensed into $20 \mathrm{ml}$ sterile nutrient broth and incubated for another 4 hours to standardise the culture to $0.5 \mathrm{McF}$ arland's standard $\left(10^{6} \mathrm{cfu} / \mathrm{ml}\right)$ before use as described by Oyeleke et al. [15].

\subsection{Antibiotic Sensitivity Profile of the Bacteria Isolated from Cosmetics}

The antibiotic sensitivity profile was investigated in order to compare the sensitivity of the microorganisms to the different conventional antibiotics. The disc diffusion method described by Bauer et al. [16] was used to determine the susceptibility and resistance of the organisms to the antibiotics. Twenty milliliter of sterile Mueller-Hilton agar was aseptically poured into sterile Petri dishes and allowed to gel. Each plate was seeded with the test organism before aseptically introducing the antibiotic disc with sterile forceps onto the surface of the solidified Mueller Hilton agar plate and incubated at $37^{\circ} \mathrm{C}$ for 24 hours. After incubation, clear zones around the disk were measured in millimeter and recorded as the zones of inhibition. Diameters of zone of inhibition was measured with a calibrated ruler and then compared with clinical and laboratory standards institute standard for bacteria sensitivity or resistance to the antibiotic. Seeded plates without antibiotic disk served as the control.

\subsection{Microgravity of the Most Frequently Isolated Microorganism from Cosmetics}

The most frequently isolated microorganism was streak on a sterile nutrient agar plates and was subjected to microgravity. The most frequently isolated organism was subjected to microgravity at $2 \mathrm{rmp}$ for 5 minutes, $20 \mathrm{rmp}$ for 10 minutes up to 30 minutes at 5 minutes interval using Clinostat and incubated for $24 \mathrm{hrs}$.

\subsection{Antibiotic Sensitivity Profile of the Bacteria Subjected to Microgravity}

The in vitro antibiotic susceptibility test of most frequent microorganism isolated from the cosmetics subjected to microgravity was done using disc diffusion method described by Bauer et al. [16].

\subsection{Statistical Analysis of Data Obtained}

All experiments were replicated three times and data obtained were subjected to one way analysis of variance, while the means were compared by Duncan's New Multiple Range Test at 95\% confidence interval using Statistical Package for Social Sciences version 16.0. Differences were considered significant at $\mathrm{p} \leq 0.05$.

\section{Results}

Table 1. Rate of occurrence of different bacteria isolated from cosmetics employed in the course of the study.

\begin{tabular}{lll}
\hline Bacteria & $\begin{array}{l}\text { Number of sample } \\
\text { tested positive }\end{array}$ & $\begin{array}{l}\text { Frequency } \\
\text { distribution (\%) }\end{array}$ \\
\hline Staphylococcus aureus & 11 & 34.38 \\
Pseudomonas aeruginosa & 7 & 21.88 \\
Escherichia coli & 5 & 15.63 \\
Proteus mirabilis & 3 & 9.38 \\
Bacillus cereus & 3 & 9.38 \\
Proteus vulgaris & 2 & 6.25 \\
Bacillus subtilis & 1 & 3.13 \\
Total & 32 & 100.03 \\
\hline
\end{tabular}

The rate of occurrence of different bacteria isolated from cosmetics is presented in Table 1. Staphylococcus aureus was the most predominant bacteria isolated in the course of the research with frequency distribution $(34.38 \%)$, followed by Pseudomonas aeruginosa (21.88\%), Escherichia coli (15.63\%), Proteus Mirabilis (9.38\%), Proteus vulgaris $(6.25 \%)$ and Bacillus subtilis (3.13\%).

Table 2. Rate of occurrence of different fungal isolated from cosmetics employed in the course of the study.

\begin{tabular}{lll}
\hline Fungi & $\begin{array}{l}\text { Number of sample } \\
\text { tested positive }\end{array}$ & $\begin{array}{l}\text { Frequency } \\
\text { distribution (\%) }\end{array}$ \\
\hline Trichoderma piluliferum & 3 & 60 \\
Neocosmospora vasinfecta & 2 & 40 \\
Total & 5 & 100 \\
\hline
\end{tabular}

The rate of occurrence of different fungi isolated from cosmetics is presented in Table 2. Trichoderma piluliferum was the predominant fungi isolated in the course of the research. 
Table 3. Antibiotics sensitivity pattern $(\mathrm{mm})$ of bacteria isolated from cosmetics.

\begin{tabular}{|c|c|c|c|c|c|c|c|}
\hline Antibiotics & S. aureus & B. subtilis & B. cereus & Pseu. Aeruginosa & P.vulgaris & P. mirabilis & E. coli \\
\hline SXT & $19.00 \pm 1.00 \mathrm{~g}$ & $10.33 \pm 0.58^{f}$ & $10.67 \pm 0.5 f$ & $0.00 \pm 0.00^{\mathrm{a}}$ & $0.00 \pm 0.00^{\mathrm{a}}$ & $0.00 \pm 0.00^{\mathrm{a}}$ & $7.33 \pm 0.58^{\mathrm{c}}$ \\
\hline CPX & $16.33 \pm 0.58^{f}$ & $11.33 \pm 0.58^{\mathrm{fg}}$ & $10.00 \pm 0.00^{\text {ef }}$ & $0.00 \pm 0.00^{\mathrm{a}}$ & $6.33 \pm 0.58^{\mathrm{de}}$ & $5.33 \pm 0.58^{\text {bcd }}$ & $7.33 \pm 0.58^{\mathrm{c}}$ \\
\hline $\mathrm{AM}$ & $0.00 \pm 0.00^{\mathrm{a}}$ & $0.00 \pm 0.00^{\mathrm{a}}$ & $0.00 \pm 0.00^{\mathrm{a}}$ & $0.00 \pm 0.00^{\mathrm{a}}$ & $0.00 \pm 0.00 \mathrm{a}$ & $0.00 \pm 0.00 \mathrm{a}$ & $8.67 \pm 0.58^{d}$ \\
\hline $\mathrm{CN}$ & $14.00 \pm 1.00^{\mathrm{e}}$ & $13.00 \pm 1.00^{\mathrm{hi}}$ & $13.67 \pm 0.58^{\mathrm{h}}$ & $0.00 \pm 0.00^{\mathrm{a}}$ & $0.00 \pm 0.00^{\mathrm{a}}$ & $6.33 \pm 1.15^{\mathrm{de}}$ & $13.00 \pm 1.00^{f}$ \\
\hline PEF & $16.33 \pm 0.58^{f}$ & $8.00 \pm 0.00^{\mathrm{e}}$ & $9.00 \pm 1.00^{\mathrm{de}}$ & $0.00 \pm 0.00^{\mathrm{a}}$ & $0.00 \pm 0.00^{\mathrm{a}}$ & $6.67 \pm 0.58^{\mathrm{e}}$ & $10.67 \pm 1.15^{\mathrm{e}}$ \\
\hline S & $12.67 \pm 1.15^{\mathrm{d}}$ & $8.33 \pm .0 .58^{\mathrm{e}}$ & $8.33 \pm 1.52^{\mathrm{d}}$ & $0.00 \pm 0.00^{\mathrm{a}}$ & $5.67 \pm 0.58^{\mathrm{cd}}$ & $4.67 \pm 0.58^{\mathrm{bc}}$ & $0.00 \pm 0.00^{\mathrm{a}}$ \\
\hline APX & $0.00 \pm 0.00^{\mathrm{a}}$ & $0.00 \pm 0.00^{\mathrm{a}}$ & $0.00 \pm 0.0 .00^{\mathrm{a}}$ & $0.00 \pm 0.00^{\mathrm{a}}$ & $0.00 \pm 0.00^{\mathrm{a}}$ & $11.00 \pm 1.00^{\mathrm{g}}$ & $0.00 \pm 0.00^{\mathrm{a}}$ \\
\hline $\mathrm{R}$ & $16.33 \pm 0.58^{\mathrm{f}}$ & $12.67 \pm 1.15^{\mathrm{hi}}$ & $13.00 \pm 0.00^{\text {gh }}$ & $0.00 \pm 0.00^{\mathrm{a}}$ & $5.33 \pm 0.58^{b}$ & $4.33 \pm 0.58^{b}$ & $4.67 \pm 1.15^{b}$ \\
\hline $\mathrm{E}$ & $12.33 \pm 0.58^{\mathrm{d}}$ & $13.67 \pm 0.58^{\mathrm{i}}$ & $12.00 \pm 0.00^{\mathrm{g}}$ & $0.00 \pm 0.00^{\mathrm{a}}$ & $0.00 \pm 0.00^{\mathrm{a}}$ & $0.00 \pm 0.00^{\mathrm{a}}$ & $0.00 \pm 0.00^{\mathrm{a}}$ \\
\hline $\mathrm{CH}$ & $11.00 \pm 1.00^{\mathrm{c}}$ & $7.67 \pm 0.58^{\mathrm{de}}$ & $5.33 \pm 0.58^{c}$ & $0.00 \pm 0.00^{\mathrm{a}}$ & $4.33 \pm 0.58^{b}$ & $0.00 \pm 0.00^{\mathrm{a}}$ & $8.33 \pm 0.58^{\mathrm{cd}}$ \\
\hline SP & $10.67 \pm 0.58^{\mathrm{c}}$ & $5.00 \pm 0.00^{\mathrm{c}}$ & $3.33 \pm 0.58^{\mathrm{b}}$ & $0.00 \pm 0.00^{\mathrm{a}}$ & $0.00 \pm 0.00^{\mathrm{a}}$ & $5.67 \pm 0.58^{\text {cde }}$ & $8.00 \pm 1.00^{\mathrm{cd}}$ \\
\hline $\mathrm{AU}$ & $8.33 \pm 0.58^{b}$ & $3.67 \pm 0.58^{\mathrm{b}}$ & $0.00 \pm 0.00^{\mathrm{a}}$ & $0.00 \pm 0.00^{\mathrm{a}}$ & $7.00 \pm 1.00^{\mathrm{ef}}$ & $14.00 \pm 1.00^{\mathrm{h}}$ & $8.67 \pm 0.58^{d}$ \\
\hline OFX & $12.67 \pm 1.15^{\mathrm{d}}$ & $6.67 \pm 1.53^{\mathrm{d}}$ & $5.00 \pm 1.00^{\mathrm{c}}$ & $4.67 \pm 0.58^{b}$ & $8.67 \pm 0.58^{\mathrm{g}}$ & $13.67 \pm 0.58^{\mathrm{h}}$ & $8.67 \pm 0.58^{\mathrm{d}}$ \\
\hline
\end{tabular}

Data are presented as Mean \pm S.D. Values with the same superscript letter (s) along the same column are not significantly different (P<0.05).

Key: SXT = Septrin (30ug), CPX = Ciprofloxacin (10ug), AM = Amoxicillin (10ug), CN = Gentamycin (10ug), PEF = Pefloxacin (30ug), S = Streptomycin (30ug), APX = Ampiclox (30ug), Z = Zinnacef (20ug), R = Rocephin (25ug), E = Erythromycin (10ug), CH = Chloramphenicol (30ug), SP = Sparfloxacin (10ug), AU = Augmentin (30ug), OFX = Tarivid (10ug)

The antibiotics sensitivity pattern of bacteria isolated from cosmetics are presented in Table 3. The bacteria isolated from cosmetic were Staphylococcus aureus, Bacillus subtilis, Bacillus cereus, Pseudomonas aeruginosa, Proteus vulgaris, Proteus mirabilis and Escherichia coli. Pseudomonas aeruginosa was the most resistant bacteria to antibiotics in the course of the research.

Table 4. Antibiotics resistance pattern $(\mathrm{mm})$ of the most frequently isolated microorganism from cosmetics (Stapylococcus aureus) subjected to microgravity.

\begin{tabular}{|c|c|c|c|c|c|c|c|}
\hline Antibiotics & S. aureus & $\begin{array}{l}\text { S. aureus@ } \\
\text { 2rpm for } 5 \text { mins }\end{array}$ & $\begin{array}{l}\text { S. aureus@ } \\
\text { 20rpm for } 10 \text { mins }\end{array}$ & $\begin{array}{l}\text { S. aureus@ } \\
\text { 20rpm for } 15 \text { mins }\end{array}$ & $\begin{array}{l}\text { S. aureus@20rpm } \\
\text { for } 20 \text { mins }\end{array}$ & $\begin{array}{l}S . \text { aureus@ } \\
\text { 20rpm for } 25 \text { mins }\end{array}$ & $\begin{array}{l}\text { S. aureus@ } \\
\text { 20rpm for } 30 \\
\text { mins }\end{array}$ \\
\hline SXT & $19.00 \pm 1.00^{\mathrm{g}}$ & $18.67 \pm 1.15^{\mathrm{h}}$ & $10.33 \pm 0.58^{\mathrm{e}}$ & $10.00 \pm 0.00^{\mathrm{f}}$ & $10.00 \pm 0.00^{\mathrm{e}}$ & $9.67 \pm 0.58^{\mathrm{e}}$ & $9.67 \pm 0.58^{\mathrm{e}}$ \\
\hline CPX & $16.33 \pm 0.58^{f}$ & $16.00 \pm 0.00^{\mathrm{g}}$ & $13.00 \pm 1.00^{\mathrm{f}}$ & $12.33 \pm 0.58^{\mathrm{g}}$ & $12.33 \pm 0.58^{\mathrm{g}}$ & $12.00 \pm 0.00^{\mathrm{g}}$ & $12.00 \pm 0.00^{\mathrm{g}}$ \\
\hline $\mathrm{AM}$ & $0.00 \pm 0.00^{\mathrm{a}}$ & $0.00 \pm 0.00^{\mathrm{a}}$ & $0.00 \pm 0.00^{\mathrm{a}}$ & $0.00 \pm 0.00^{\mathrm{a}}$ & $0.00 \pm 0.00^{\mathrm{a}}$ & $0.00 \pm 0.00^{\mathrm{a}}$ & $0.00 \pm 0.00^{\mathrm{a}}$ \\
\hline $\mathrm{CN}$ & $14.00 \pm 1.00^{\mathrm{e}}$ & $6.67 \pm 1.15^{\mathrm{b}}$ & $6.33 \pm 0.58^{c}$ & $6.33 \pm 0.58^{\mathrm{d}}$ & $6.00 \pm 0.00^{\mathrm{c}}$ & $4.33 \pm 0.58^{b}$ & $4.33 \pm 0.58^{b}$ \\
\hline PEF & $16.33 \pm 0.58^{\mathrm{f}}$ & $16.33 \pm 0.58^{\mathrm{g}}$ & $12.33 \pm 0.58^{\mathrm{f}}$ & $12.33 \pm 0.58^{\mathrm{g}}$ & $12.00 \pm 0.00^{\mathrm{g}}$ & $12.00 \pm 0.00^{\mathrm{g}}$ & $10.67 \pm 1.15^{\mathrm{f}}$ \\
\hline S & $12.67 \pm 1.15^{\mathrm{d}}$ & $12.33 \pm 0.58^{\mathrm{e}}$ & $8.33 \pm 0.58^{\mathrm{d}}$ & $8.33 \pm 0.58^{\mathrm{e}}$ & $6.33 \pm 0.58^{\mathrm{c}}$ & $6.00 \pm 0.00^{\mathrm{c}}$ & $6.00 \pm 0.00^{\mathrm{c}}$ \\
\hline APX & $0.00 \pm 0.00^{\mathrm{a}}$ & $0.00 \pm 0.00^{\mathrm{a}}$ & $0.00 \pm 0.00^{\mathrm{a}}$ & $0.00 \pm 0.00^{\mathrm{a}}$ & $0.00 \pm 0.00^{\mathrm{a}}$ & $0.00 \pm 0.00^{\mathrm{a}}$ & $0.00 \pm 0.00^{\mathrm{a}}$ \\
\hline Z & $8.00 \pm 0.00^{\mathrm{b}}$ & $0.00 \pm 0.00^{\mathrm{a}}$ & $0.00 \pm 0.00^{\mathrm{a}}$ & $0.00 \pm 0.00^{\mathrm{a}}$ & $0.00 \pm 0.00^{\mathrm{a}}$ & $0.00 \pm 0.00^{\mathrm{a}}$ & $0.00 \pm 0.00^{\mathrm{a}}$ \\
\hline $\mathrm{R}$ & $16.33 \pm 0.58^{f}$ & $14.33 \pm 0.58^{\mathrm{f}}$ & $10.33 \pm 0.58^{\mathrm{e}}$ & $8.33 \pm 0.58^{\mathrm{e}}$ & $6.33 \pm 0.58^{\mathrm{c}}$ & $5.67 \pm 0.58^{\mathrm{c}}$ & $5.67 \pm 0.58^{\mathrm{c}}$ \\
\hline E & $12.33 \pm 0.58^{\mathrm{d}}$ & $6.67 \pm 1.15^{\mathrm{b}}$ & $6.33 \pm 0.58^{\mathrm{c}}$ & $4.33 \pm 0.58^{\mathrm{c}}$ & $4.00 \pm 0.00^{\mathrm{b}}$ & $4.00 \pm 0.00^{\mathrm{b}}$ & $3.67 \pm 0.58^{\mathrm{b}}$ \\
\hline $\mathrm{CH}$ & $11.00 \pm 1.00^{\mathrm{c}}$ & $6.33 \pm 0.58^{\mathrm{b}}$ & $6.33 \pm 0.58^{c}$ & $6.00 \pm 0.00^{\mathrm{d}}$ & $6.00 \pm 0.00^{c}$ & $5.67 \pm 0.58^{\mathrm{c}}$ & $5.33 \pm 1.15^{\mathrm{c}}$ \\
\hline SP & $10.67 \pm 0.58^{\mathrm{c}}$ & $10.00 \pm 0.00^{\mathrm{d}}$ & $8.33 \pm 0.58^{\mathrm{d}}$ & $8.33 \pm 0.58^{\mathrm{e}}$ & $8.33 \pm 0.58^{\mathrm{d}}$ & $8.00 \pm 0.00^{\mathrm{d}}$ & $7.67 \pm 0.58^{d}$ \\
\hline OFX & $12.67 \pm 1.15^{\mathrm{d}}$ & $12.33 \pm 0.58^{\mathrm{e}}$ & $12.33 \pm 0.58^{\mathrm{f}}$ & $12.33 \pm 0.58^{\mathrm{g}}$ & $11.00 \pm 1.00^{\mathrm{f}}$ & $10.33 \pm 0.58^{\mathrm{f}}$ & $10.00 \pm 0.00^{\mathrm{ef}}$ \\
\hline
\end{tabular}

Data are presented as Mean \pm S.D. Values with the same superscript letter (s) along the same column are not significantly different (P<0.05).

Key: SXT = Septrin (30ug), CPX = Ciprofloxacin (10ug), AM = Amoxicillin (10ug), CN = Gentamycin (10ug), PEF = Pefloxacin (30ug), $\mathrm{S}=\mathrm{Streptomycin}$ (30ug), APX = Ampiclox (30ug), Z = Zinnacef (20ug), R = Rocephin (25ug), E = Erythromycin (10ug), CH = Chloramphenicol (30ug), SP = Sparfloxacin (10ug), AU = Augmentin (30ug), OFX = Tarivid (10ug)

Antibiotics resistance pattern $(\mathrm{mm})$ of most frequently isolated microorganism from cosmetics (Staphylococcus aureus) subjected to microgravity are shown in Table 4 . The Staphylococcus aureus was subject to microgravity at $2 \mathrm{rpm}$ for $5 \mathrm{mins}, 20 \mathrm{rpm}$ for $10 \mathrm{mins}, 20 \mathrm{rpm}$ for $15 \mathrm{mins}, 20 \mathrm{rpm}$ for $20 \mathrm{mins}, 20 \mathrm{rpm}$ for $25 \mathrm{mins}$ and $20 \mathrm{rpm}$ for $30 \mathrm{mins}$. The bacteria grown under actual reduced gravity conditions exhibited resistance to antibiotics more than they do under earth gravity.

\section{Discussion}

Most of the cosmetics employed in the course of the study were contaminated with microorganisms. Up to $9.09 \%$ (2 out of 22) of the cosmetics were not contaminated with microorganisms, approximately $90.91 \%$ (20 out of 22 ) of the cosmetics were contaminated with microorganisms. The isolated microorganisms included Staphylococcus aureus, Pseudomonas aeruginosa, Escherichia coli, Proteus mirabilis, Bacillus cereus, P. vulgaris, B. subtilis, 
Trichoderma piluliferum and Neocosmospora vasinfecta.. Staphylococcus aureus and P. aeruginosa were the most frequent isolated bacteria from the cosmetics. This is in accordance with the report of Lundov et al. [1] who reported that pathogenic microorganisms such as $S$. aureus and Pseudomonas aeruginosa are frequently found in contaminated cosmetics. Staphylococcus aureus were found to be the most predominant microorganisms and/or bacteria with highest frequency distribution (34.38\%) isolated from cosmetics use in the course of the research.

The bacteria grown under actual reduced gravity condition exhibited resistance to antibiotics. This is in line with the finding of Lynch et al. [17] and Allen et al. [18]. Previous studies have shown that bacteria grown under either actual reduced gravity or Modeled Reduced Gravity (MRG) conditions, surprisingly, exhibited resistance to multiple antibiotics $[17,18]$ and become more virulent, which has important potential impacts for human health $[2,19,20]$. The resistance to antibiotic of bacteria grown under actual reduced gravity condition could be as a result of bacteria under these conditions has enhanced growth [11, 21, 22], secondary metabolite production [23], biofilm formation [24] and extracellular polysaccharide production [22]. The resistance of the $S$. aureus to antibiotics tends to increase with increased in revolution per minutes (rpm) at which the microorganism was subjected. This is in agreement with the report of Matin et al. [14] who reported that a large body of work conducted with bacteria grown under conventional normal gravity conditions over the last two or so decades has shown that increased bacterial virulence is accompanied with increased resistance to antimicrobial stresses. The large-scale physiological effects of microgravity-induced stress on animals and plants are relatively well known. For example, in humans, microgravity conditions result in bone loss, upwards to $3 \%$ per month [25-27], permutations to both the adaptive and innate immune systems [28], and an increased potential risk of bacterial and viral infections [29, 30].

\section{Conclusion}

The most frequently isolated bacteria namely Staphylococcus aureus exhibited greater resistance to antibiotics under stimulated microgravity condition than one under earth gravity condition at different time. The resistance of the $S$. aureus to antibiotics tends to increase with increased in revolution per minutes (rpm) at which the bacterium was subjected.

\section{References}

[1] Lundov, M. D., Moesby, L., Zachariae, C. and Johansen, J. D. (2009). Contamination versus cosmetics: A review on legislation, usage, infections and contact allergy. Contact Dermatitis, 60: 70-78.

[2] Rosenzweig, J. A., Abogunde, O., Thomas, K, Lawal, A., Nguyen, Y., Sodipe, A. and Jejelo, O. (2010). Spaceflight and modeled microgravity effects on microbial growth and virulence. Applied Microbiology and Biotechnology, 85: 885-891.
[3] Foster, J. W. and Spector, M. P. (1995). How Salmonella survive against the odds. Annual Review Microbiology, 49: 145-174.

[4] Cavicchioli, R., Thomas, T. and Curmi, P. M. (2000). Cold stress response in Archaea. Extremophiles, 4: 321-331.

[5] Audia, J. P., Webb, C. C. and Foster, J. W. (2001). Breaking through the acidbarrier: an orchestrated response to proton stress by enteric bacteria. International Journal of Medical Microbiology, 291: 97-106.

[6] Hecker, M. and Volker, U. (2001). General stress response of Bacillus subtilis and other bacteria. Advances in Microbial Physiology, 44: 35-91.

[7] Hengge-Aronis, R. (2002). Recent insights into the general stress response regulatory network in Escherichia coli. Journal of Molecular Microbiology and Biotechnology, 4: 341-346.

[8] Poolman, B., Blount, P., Folgering, J. H., Friesen, R. H., Moe, P. C. and Heide. T. V. (2002). How do membrane proteins sense water stress? Molecular Microbiology, 44: 889-902.

[9] Dickson, K. J. (1991). Summary of biological spaceflight experiments with cells. ASGSB Bull, 4: 151-260.

[10] Mishra, S. K. and Pierson, D. L. (1992). Spaceflight: effects on microorganisms. pp. 53-60. In J. Lederberg (ed.), Encyclopedia of microbiology. vol. 4. Academic Press, Inc., San Diego, Calif.

[11] Kacena, M. A., Merrell, G. A., Manfredi, B., Smith, E. E., Klaus, D. M. and Todd, P. (1999). Bacterial growth in spaceflight: logistic growth curve parameters for Escherichia coli and Bacillus subtilis. Applied Microbiology and Biotechnology, 51: 229-234.

[12] Klaus, D. M. (2002). Space microbiology: microgravity and microorganisms. p. 2996-3004. InG. Bitton (ed.), Encyclopedia of environmental microbiology. John Wiley \& Sons, Inc., New York, N. Y.

[13] Nickerson, C. A., Ott, C. M., Wilson, J. W., Ramamurthy, R., LeBlanc, C. L., Honer zu Bentrup, K., Hammond, T. and Pierson, D. L. (2003). Low-shear modeled microgravity: a global environmental regulatory signal affecting bacterial gene expression, physiology, and pathogenesis. Journal of Microbiology Methods, 54: 1-11.

[14] Matin, A., Lynch, S. V. and Benoit, M. R. (2006). Increased bacterial resistance and virulence in simulated microgravity and its molecular basis. Gravitational and Space Biology, 19 (2): 31-41.

[15] Oyeleke, S. B., Dauda, B. E. N. and Boye, O. A. (2008). Antibacterial activity of Ficus capensis. African Journal of Biotechnology, 7 (10): 1414-1417.

[16] Bauer, A. W., Kirby, W. M., Sherris, J. C. and Turck, M. (1996). Antibiotic susceptibility testing by a standardized single disk method. American journal of Clinical Pathology, 459 (4): 493-6.

[17] Lynch, S. V., Brodie, E. L. and Matin, A. (2004). Role and regulation of sigma $S$ in general resistance conferred by lowshear simulated microgravity in Escherichia coli. Journal of Bacteriology, 186: 8207-8212. 
[18] Allen, C. A., Niesel, D. W. and Torres, A. G. (2008). The effects of low-shear stress on Adherent invasive Escherichia coli. Environmental Microbiology, 10: 1512-1525.

[19] Nickerson, C. A., Ott, C. M., Mister, S. J., Morrow, B. J., Burns-Keliher, L. and Pierson, D. L (2000). Microgravity as a novel environmental signal affecting Salmonella enteric serovar typhimurium virulence. Infection and Immunity, 68: 3147-3152.

[20] Wilson, J. W., Ott, C. M, Bentrup, Z., Ramamurthy, R., Quick, L., Porwollik, S., Cheng, P., McClelland, M., Tsaprailis, G., Radabaugh, T., Hunt, A., Fernandez, D., Richter, E., Shah, M., Kilcoyne, M., Joshi, L., Nelman-Gonzalez, M., Hing, S., Parra, M., Dumars, P., Norwood, K., Bober, R., Devich, J., Ruggles. A., Goulart, C., Rupert, M., Stodieck, L., Stafford, P., Catella, L., Schurr, M. J., Buchanan, K., Morici, L., McCracken, J., Allen, P., Baker-Coleman, C., Hammond, T., Vogel, J., Nelson, R., Pierson, D. L., Stefanyshyn-Piper, H. M. and Nickerson, C. A. (2007). Space flight alters bacterial gene expression and virulence and reveals a role for global regulator Hfq. Proceedings of National Academy of Sciences USA, 104: 16299-16304.

[21] Brown, R. B., Klaus, D. and Todd, P. (2002). Effects of space flight, clinorotation, and centrifugation on the substrate utilization efficiency of E. coli. Microgravity Science and Technology, 13: 24-29.

[22] Mauclaire, L. and Egli, M. (2010). Effect of simulated microgravity on growth and production of exopolymeric substances of Micrococcus luteus space and earth isolates. FEMS Immunology and Medical Microbiology, 59: 350-356.
[23] Demain, A. L. and Fang, A. (2001). Secondary metabolism in simulated microgravity. Chemical Record, 1: 333-346.

[24] McLean, R. J., Cassanto, J. M., Barnes, M. B. and Koo, J. H. (2001). Bacterial biofilm formation under microgravity conditions. FEMS Microbiology Letters, 195: 115-119.

[25] Lynch, S. V. and Matin, A. (2005). Travails of microgravity: Man and microbes in space. Biologist, 52 (2): 80-87.

[26] Globus, R. K. and Morey-Holton, E. R. (2009). Advances in understanding the skeletal biology of spaceflight. Gravitational and Space Biology, 22: 3-12.

[27] Stein, T. P. (2013). Weight, muscle and bone loss during space flight: Another perspective. European Journal of Applied Physiology, 113: 2171-2181.

[28] Guéguinou, N., Huin-Schohn, C., Bascove, M., Bueb, J. L., Tschirhart, E., Legrand-Frossi, C. and Frippiat, J. P. (2009). Could spaceflight-associated immune system weakening preclude the expansion of human presence beyond Earth's orbit? Journal of Leukocyte Biology, 86: 1027-1038.

[29] Ott, C. M., Crabbe, A., Wilson, J. W., Barrila, J., Castro, S. L. and Nickerson, C. A. (2012). Microbial Stress: SpaceflightInduced Alterations in Microbial Virulence and Infectious Disease Risks for the Crew. In Stress Challenges and immunity in Space; Chouker, A., Ed.; Springer-Verlag: Berlin/Heidelberg, Gemany, 2012; pp. 203-225.

[30] Mermel, L. A. (2013). Infection prevention and control during prolonged human space travel. Clinical Infection, 56: 123130. 